\title{
STUDIES ON GASTROINTESTINAL NEMATODES INFECTION IN SHEEP WITH SPECIAL REFERENCE TO HAEMONCHUS CONTORTUS
}
M.H. AL-GAABARY*,
S.A.OSMAN**,
K.M.ABO
EL-SOUD**
and A.I. HASSAN $* * * *$
*Department of Animal Medicine, Faculty of Veterinary Medicine, Kafr Elsheikh University, Kafr Elsheikh 33516, Egypt.
**Department of Veterinary Medici ne, Faculty of Agriculture and Veterinary Medicine, Qassim University.
***Department of Pharmacognosy, Faculty of Pharmacy, Tanta University, Egypt
****Directorate of Veterinary Medicine in Gharbia Governorate, General Organization for Veterinary Services, Ministry of Agriculture, Egypt

\begin{tabular}{ll}
\hline ABSTRACT \\
\hline Received: 17/1/2012 \\
This study was carried out to investigate clinical, \\
epidemiological and histopathological findings associated with \\
gastrointestinal nematodes infection in sheep with special \\
reference to Haemonchus contortus infection during the period \\
from January, 2008 to June, 2010 at Gharbia Governorate, \\
Egypt. The prevalence of gastrointestinal nematode among \\
examined sheep was 62.38\%. Trichostrongylus spp. was the \\
most detected nematode. The highest prevalence was reported in \\
females, during spring and in the age group over 2 years. The \\
clinical findings observed in infected sheep were emaciation and \\
pale mucous membrane. Infected sheep showed anemia and \\
decrease in serum total proteins, albumin and globulins levels.
\end{tabular}

Keywords: Sheep, Gastrointestinal nematode, Prevalence, Egypt.

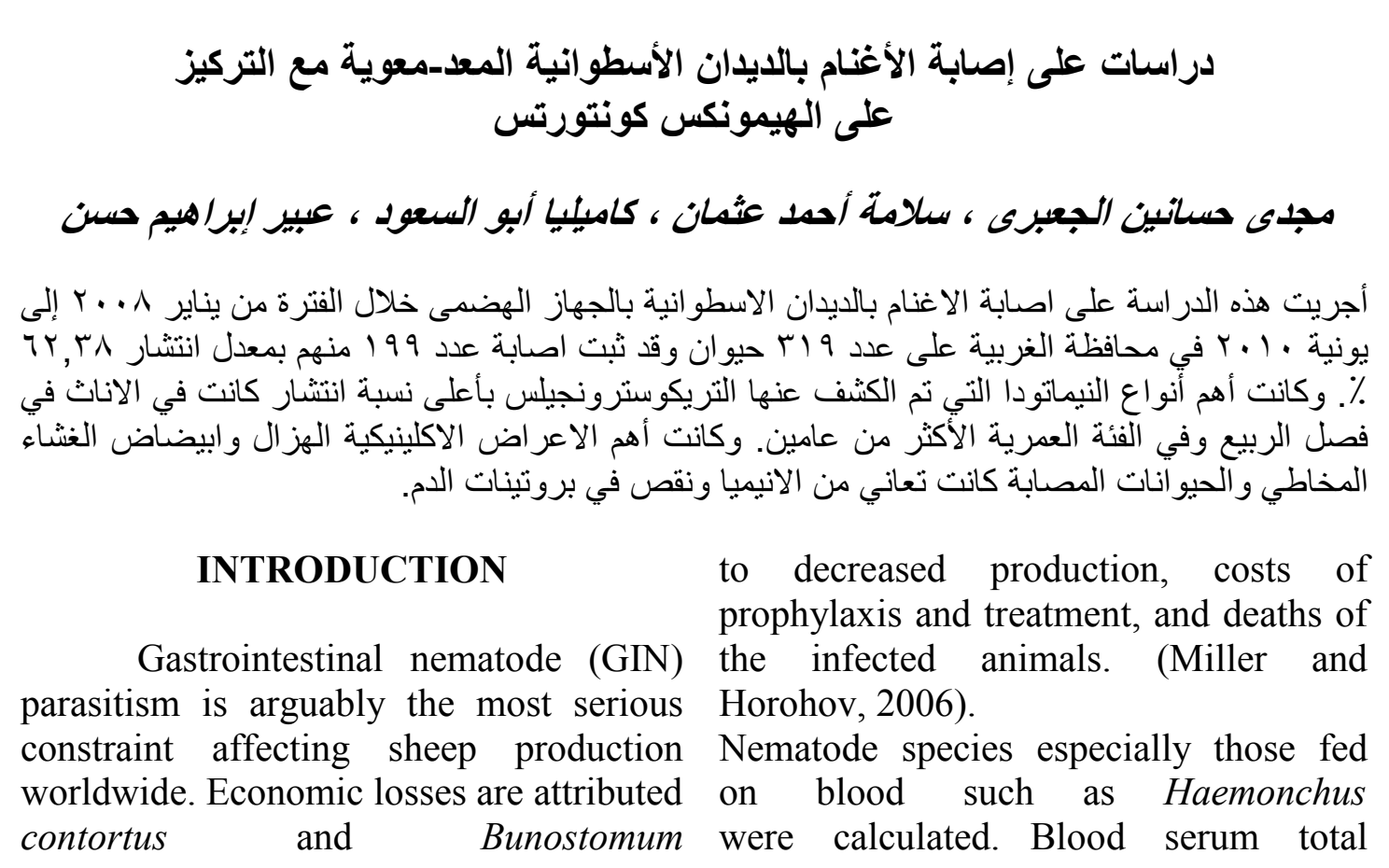


trigonocephalum are responsible for specific clinical symptoms and great economic losses to small ruminant industry. Although Haemonchus species infect all ruminants, the severity of Haemonchus contortus infection is more pronounced in sheep where it is linked to severe anemia, diarrhea, loss of body weight and death (Agarwal and Banerjee, 2007). The objective of this study is to investigate the clinical, epidemiological, and histopathological findings associated with gastrointestinal nematodes in sheep at Gharbia Governorates, Epypt.

\section{MATERIALS and METHODS}

\section{Animals:-}

Three hundred and nineteen sheep belonging to 8 flocks of different age and sex (Table 1) were used in this study during the period from January, 2008 to June, 2010. All flocks were depending on grazing.

\section{Clinical examination}

All sheep used in this study were subjected to clinical examination according to. Kelly (1984).

\section{Samples:-}

\subsection{Fecal samples}

Fecal samples were examined macroscopically and microscopically using concentration floatation technique and the positive samples were subjected to fecal egg count, fecal culture, and larval identification according to Soulsby (1982).

\subsection{Blood samples}

Two blood samples were collected from each infected animal; one with anti coagulant to be used for hematological examination and the other without to be used for serum separation. These samples were collected via jugular vein puncture. Erythrocytic cell counts (RBCs), hemoglobin concentration $(\mathrm{Hb})$ and Packed Cell Volume (PCV) were estimated according to Coles (1989). Moreover, $\mathrm{MCV}, \mathrm{MCH}$ and $\mathrm{MCHC}$ also proteins, albumin and globulins were determined using commercial kits according to Doumas (1971) and Henry (1974).

\section{Epidemiological investigations}

Some epidemiological parameters associated with gastrointestinal nematodes infection were estimated according to Martin et al. (1987).

\section{Post mortem examination:-}

Five Haemonchus contortus infected sheep were slaughtered and their abomasa were examined grossly and histopathologically. Adult worms were collected for identification. Suitable portion of the infected abomasum, showing gross lesions was collected and fixed in $10 \%$ neutral buffered formalin solution to be used for histopathological examination.

\subsection{Identification of adult worms from infected abomasa:-}

Adult worms were collected from infected abomasa, washed in physiological saline, fixed in glycerinalcohol then embedded in Canada-blasm on glass slides and identified according to Soulsby (1982).

\subsection{Histopathological examination:-}

The fixed infected abomasa were embedded in paraffin wax. Five microns thick paraffin sections were prepared and stained with Haematoxylene and Eosin (H\&E) and examined microscopically according to Drurag and Wallington (1980).

\section{Statistical analysis:-}

Statistical analysis was carried out by using statistical soft ware program (GMP for windows version 5.1, SAS Institute, Cary, NC, USA). Differences between means at $\mathrm{P}<0.05$ were considered significant.

The prevalence of gastrointestinal 


\section{RESULTS}

Prevalence and percentage of different gastrointestinal nematodes

Out of 319 examined sheep, 199 were found to be infected with gastrointestinal nematodes via parasitological examination representing $62.38 \%$. (Figure 1). The highest infection was recorded by Trichostrongylus species was 59.25\%, (Haemonchms 30\%), followed by Strongyloides $(13.79 \%)$ then Trichuris $(0.94 \%)$ and Nematodirus (0.63\%). Concerning the seasonal distribution of parasitic infestation, higher prevalence was recorded in spring $(71.59 \%)$ followed by autumn $(70.31 \%)$ then winter $(68.91 \%)$ and finally summer (43.01\%).

The prevalence of the recovered $3^{\text {rd }}$ stage larvae from fecal culture revealed that the predominant species in winter were Haemonchus (30\%) followed by Bunstomum (20\%) and Trichostrongylus species $(20 \%)$. While, in spring were Haemonchus (30\%) and Trichostrongylus species (30\%) and in summer Bunstomum was the most predominant species $(30 \%)$ followed by Haemonchus (20\%) and Strongyloides (20\%) then in autumn Haemonchus was the most predominant species $(30 \%)$ followed by Trichostrongylus axei (20\%). nematodes in relation to animal age and sex was illustrated in Table ( $2 \& 3)$.

\section{Clinical findings:-}

Clinical findings were illustrated in Table (4).

\section{Hematological findings:-}

The hematological and serum biochemical changes that associated with gastrointestinal nematodes infestation in the examined sheep were illustrated in Table (5 and 6).

\section{Post mortem findings:-}

\section{Gross lesions}

Thickening, hyperemia and small ulceration in addition to petechial hemorrhage at the site of worm attachment were observed in infested abomasa. Abomasal contents were dark in color and the adult worms were present grossly.

\section{Identification of the recovered worms}

The detected worms were identified as Haemonchus spp.

\section{Histopathological findings}

Histopathological changes in abomasa infected with Haemonchus, were illustrated in Figures $(2-6)$

Table 1: Locality, number, sex and ages of the examined animals.

\begin{tabular}{|c|c|c|c|c|c|c|c|c|c|}
\hline \multirow[b]{3}{*}{ Locality } & \multirow{3}{*}{ 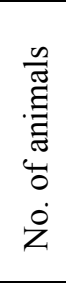 } & \multicolumn{8}{|c|}{ Sex and age } \\
\hline & & \multicolumn{4}{|c|}{ Male } & \multicolumn{4}{|c|}{ Female } \\
\hline & & 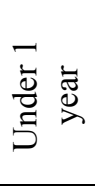 & 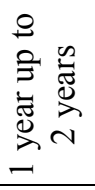 & 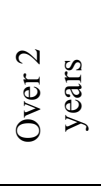 & $\stackrel{\text { त्ञ }}{\circ}$ & 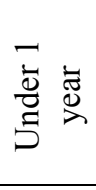 & 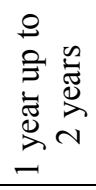 & $\stackrel{\sim}{\infty}$ & 豞 \\
\hline Kohafa & 54 & 4 & 8 & 3 & 15 & 8 & 15 & 16 & 39 \\
\hline Elmohami & 43 & 6 & 6 & 2 & 14 & 4 & 16 & 9 & 29 \\
\hline Kafrelzait & 20 & 3 & 2 & 0 & 5 & 5 & 5 & 5 & 15 \\
\hline Kotor & 20 & 7 & 0 & 3 & 10 & 7 & 0 & 3 & 10 \\
\hline Nawag & 12 & 2 & 1 & 0 & 3 & 1 & 4 & 4 & 9 \\
\hline Sprbay & 91 & 13 & 8 & 3 & 24 & 27 & 29 & 11 & 67 \\
\hline Tanta & 70 & 40 & 1 & 1 & 42 & 6 & 18 & 4 & 28 \\
\hline Zefta & 9 & 2 & 1 & 0 & 3 & 0 & 5 & 1 & 6 \\
\hline Total & 319 & 77 & 27 & 12 & 116 & 58 & 92 & 53 & 203 \\
\hline
\end{tabular}


Table 2: Prevalence of parasitic gastrointestinal nematodes in relation to age.

\begin{tabular}{lccc}
\hline Age & No. of examined sheep & No. of infected sheep & $\%$ \\
\hline Under 1 year & 135 & 62 & 45.93 \\
& 119 & 86 & 72.27 \\
1 year up to 2 years & 65 & 51 & 78.46 \\
Over 2 years & 319 & 199 & 62.38 \\
Total &
\end{tabular}

Significant variation was recorded among different age groups $(\mathrm{P}<0.001)$

Table 3: Prevalence of gastrointestinal nematodes in relation to sex

\begin{tabular}{lccc}
\hline Sex & No. of examined sheep & No. of infected sheep & $\%$ \\
Male & 116 & 45 & 38.79 \\
Female & 203 & 154 & 75.86 \\
Total & 319 & 199 & 62.38 \\
\hline
\end{tabular}

Significant variation was recorded among different sex $(\mathrm{P}<0.001)$

Table 4: Clinical signs in relation to degree of infection.

\begin{tabular}{lcll}
\hline Degree of infestation & $\begin{array}{l}\text { No. of } \\
\text { animals }\end{array}$ & \multicolumn{1}{c}{ Clinical signs } \\
\hline $\begin{array}{l}\text { Severe } \\
\text { (over } 1000 \text { Epg) }\end{array}$ & 47 & 14.73 & $\begin{array}{l}\text { Severe emaciation } \\
\text { wool easily detached } \\
\text { pale mucous membrane } \\
\text { diarrhea } \\
\text { bottle jaw in 2 cases }\end{array}$ \\
\hline $\begin{array}{l}\text { Moderate } \\
(500 \text { and } 1000 \mathrm{Epg})\end{array}$ & 56 & 17.55 & $\begin{array}{l}\text { Emaciation } \\
\text { soft feces in some cases } \\
\text { pale mucous membrane }\end{array}$ \\
\hline $\begin{array}{l}\text { Low } \\
\text { (less than } 500 \mathrm{Epg})\end{array}$ & 96 & 30.09 & $\begin{array}{l}\text { Vary from apparent healthy without clinical signs to } \\
\text { poor growth or slight emaciation and diarrhea }\end{array}$ \\
\hline
\end{tabular}

Table 5: Relation between infestation and RBCs count

\begin{tabular}{|c|c|c|c|c|c|c|c|}
\hline $\begin{array}{l}\text { Degree of } \\
\text { infestation }\end{array}$ & $\begin{array}{c}\text { Fecal egg } \\
\text { count } \\
(\mathrm{EPG})\end{array}$ & $\begin{array}{c}\text { RBCs } \\
(\mathrm{mil} / \mathrm{cmm})\end{array}$ & $\begin{array}{c}\mathrm{Hb} \\
(\mathrm{gm} / \mathrm{dl})\end{array}$ & $\begin{array}{l}\text { PCV } \\
(\%)\end{array}$ & $\mathrm{MCV}$ & $\mathrm{MCH}$ & $\mathrm{MCHC}$ \\
\hline $\begin{array}{l}\text { Low } \\
\text { (less than } \\
500 \text { Epg) }\end{array}$ & $166.66 \pm 33.33^{*}$ & $4.6 \pm 0.12 *$ & $9.66 \pm 0.08$ & $31.53 \pm 0.63$ & $68.7 \pm 3.1$ & $21.04 \pm 0.71$ & $30.66 \pm 0.34$ \\
\hline $\begin{array}{l}\text { Moderate } \\
(500 \text { and } \\
1000 \mathrm{Epg})\end{array}$ & $700 \pm 57.73 *$ & $4.3 \pm 0.1^{*}$ & $8.36 \pm 0.7$ & $26.8 \pm 1.7^{*}$ & $62.22 \pm 2.87$ & $19.39 \pm 1.34$ & $31.12 \pm 1.12$ \\
\hline $\begin{array}{l}\text { Severe } \\
\text { (Over } \\
1000 \mathrm{Epg} \text { ) }\end{array}$ & $4133.33 \pm 2535.9^{*}$ & $4.1 \pm 0.1^{*}$ & $7.13 \pm 1.16$ & $22.66 \pm 4.06^{*}$ & $54.85 \pm 8.79 *$ & $17.27 \pm 2.49^{*}$ & $31.69 \pm 0.7$ \\
\hline Negative & -ve & $5.2 \pm 0.16$ & $10.46 \pm 0.52$ & $33.16 \pm 0.83$ & $63 \pm 1.04$ & $19.85 \pm 0.64$ & $31.51 \pm 0.8$ \\
\hline
\end{tabular}

(*) Significant at $\mathrm{P} \leq 0.05$ 
Table 6: Relation between infestation and serum biochemical analysis

\begin{tabular}{|c|c|c|c|c|c|}
\hline $\begin{array}{l}\text { Degree of } \\
\text { infestation }\end{array}$ & $\begin{array}{l}\text { Fecal egg count } \\
\text { (EPG) }\end{array}$ & $\begin{array}{l}\text { Serum total } \\
\text { protein } \\
(\mathrm{g} / 100 \mathrm{ml})\end{array}$ & $\begin{array}{l}\text { Serum } \\
\text { albumin } \\
(\mathrm{g} / 100 \mathrm{ml})\end{array}$ & $\begin{array}{l}\text { Serum } \\
\text { globulin } \\
(\mathrm{g} / 100 \mathrm{ml})\end{array}$ & $\begin{array}{c}\text { Albumin } \\
\text { globulin ratio } \\
\text { (A/G ratio) } \\
(\%)\end{array}$ \\
\hline $\begin{array}{l}\text { Low } \\
\text { (less than } 500 \\
\text { Epg) }\end{array}$ & $166.66 \pm 33.33^{*}$ & $9.4 \pm 0.05 *$ & $3.22 \pm 0.02 *$ & $6.17 \pm 0.07^{*}$ & $0.52 \pm 0.01$ \\
\hline $\begin{array}{l}\text { Moderate } \\
(500 \text { and } 1000 \\
\text { Epg) }\end{array}$ & $700 \pm 57.73 *$ & $8.8 \pm 0.17 *$ & $3.06 \pm 0.12^{*}$ & $5.73 \pm 0.23 *$ & $0.53 \pm 0.03$ \\
\hline $\begin{array}{l}\text { Severe } \\
\text { (Over } 1000 \text { Epg) }\end{array}$ & $4133.33 \pm 2535.9 *$ & $8.3 \pm 0.32 *$ & $3 \pm 0.17^{*}$ & $5.3 \pm 0.15^{*}$ & $0.56 \pm 0.01$ \\
\hline Negative & -ve & $11.2 \pm 0.2$ & $3.6 \pm 0.14$ & $7.53 \pm 0.33$ & $0.49 \pm 0.03$ \\
\hline
\end{tabular}

${ }^{*}$ )Significant at $\mathrm{P} \leq 0.05$

\section{prevalence of parastic gastroenteritis in sheep in Gharbia}

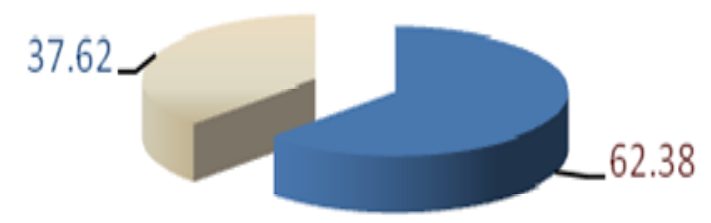

- infected sheep non infected sheep

Fig. 1

Fig. 1: Prevalence of parasitic gastrointestinal nematodes in sheep in Gharbia. 


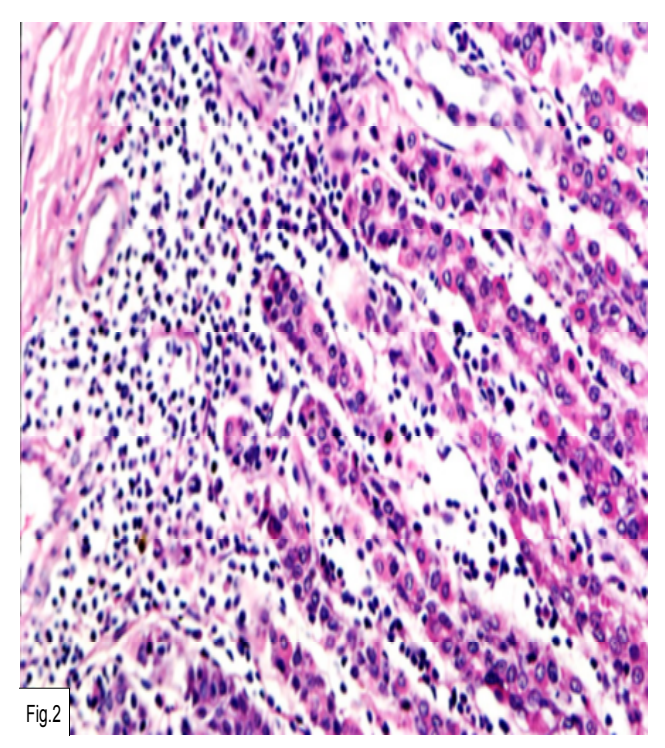

Fig.2: Mononuclear cell infiltration in between mucosal glands in Haemonchus Controtus infested abomasa. H.\&E. X $=400$.

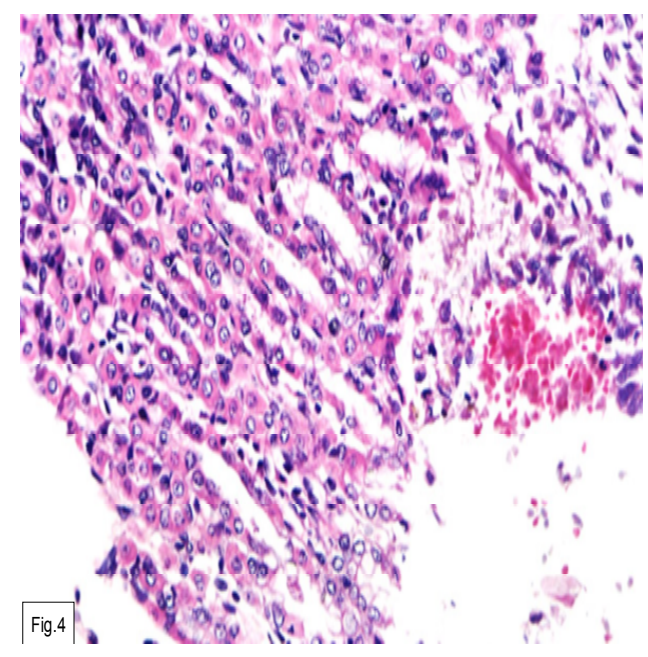

Fig. 4: Hemorrhage at abomasal wall in Haemonchus contortus infested abomasa. H.\&E. X=400.

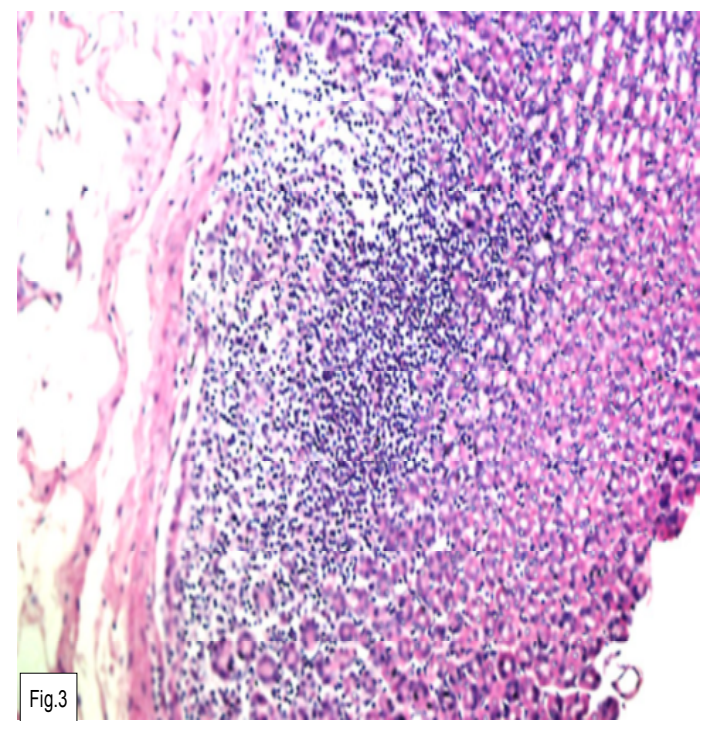

Fig.3: Mononuclear cell infiltration in between lamina propria in Haemonchus contortus infested abomasa H.\& E. X = 100.

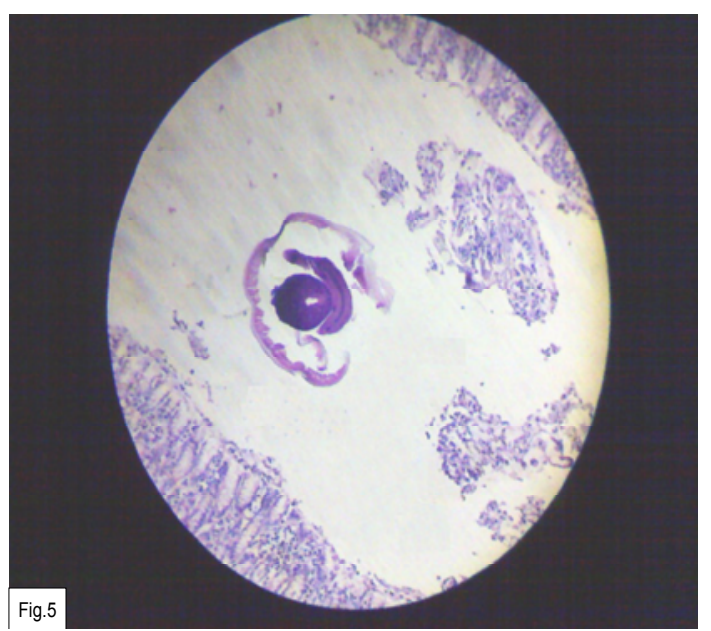

Fig. 5: Cross section of adult Haemonchus worm within the abomasal wall. $\mathrm{X}=100$. 


\section{DISCUSSION}

Sheep is considered as one of the important sectors in livestock production. Sheep may be affected with many diseases which decrease production. Parasitic gastroenteritis is one of them causing many economic losses (Miller and Horohov, 2006).

Concerning the prevalence of parasitic nematodes, out of 319 examined sheep, $199(62.38 \%)$ were proved to be infested with parasitic gastrointestinal nematodes via flotation concentration technique. Nearly similar prevalence was reported by El-Fayoumi (1989), (65.83\%). Higher prevalence was reported by Al-Gaabary et al. (2007), (71.69\%). Lower prevalence (42.66\%) was reported by Abdel-wahed and Salem (1999). The variations between the prevalence in different studies may be attributed to the type of rearing, hygiene and control measures where, sheep raised on high protein diet developed resistance to parasitic gastroenteritis (Knox and steel, 1999). In addition, the changes in climatic condition may affect the degree of infection where rain may lead to increase infection with parasitic gastroenteritis.

Highest infestation was recorded by Trichostrongylus species (59.25\%) and the lowest one recorded by Nematodirus $(0.63 \%)$. Similar results were recorded by Hashem and El-Sayed (1997) and AlGaabary et al. (2007) who found that Trichostrongylus was the predominant species in percent of $46.4 \%$ and $64.92 \%$ respectively.

Our results differed from that recorded by Gharib (1998) who found that Trichuris ovis was the most common species of gastrointestinal nematode.

Concerning the seasonal distribution of parasitic infestation, the highest prevalence was recorded in spring $(71.59 \%)$ and the lowest one was recorded in summer (43.01\%). Similar result obtained by Altaif and Issa (1983); who recorded that the peaks of worm egg counts occurred in spring and in autumn.

Our results differed from the results of Aly et al. (1994) who found lowest infestation during autumn and spring and Khalafalla et al. (2011) who reported lowest infestation during spring.

The prevalence of the recovered $3^{\text {rd }}$ stage nematode larvae from fecal culture revealed that the predominant species in winter, spring and autumn were Haemonchus $(30 \%)$ while in summer Bunstomum (30\%). Nearly similar results were obtained by Reynecke et al. (2009) who recorded that Haemonchus species was the predominant during wet seasons from October to March. Our results differed from that obtained by Horak (2003) who recorded Haemonchus species as the predominant nematodes in summer season.

Concerning age predisposition, parasitic gastrointestionl infestation was significantly different $(P<0.05)$ among age groups, where the prevalence was higher in the animals over 2 years (78.46\%) followed by animals from 1 to 2 years $(72.27 \%)$ and lastly in that below 1 year age $(45.93 \%)$. Similar results were recorded by Ramadan et al. (1992) who recorded highest worm burden in adult and old sheep. On the other hand, our results were different from that obtained by Khan et al. (2010) who found high nematode infestation in young animals than adults. Vlassoff et al. (2001) attributed these results to development and increase in immunity during increase of age. On the other hand Bonfoh et al. (1995) observed no relation between animal age and prevalence of parasitic gastroenteritis.

Concerning sex predisposition, significant variation was recorded within different sex where the prevalence rate in female animals was $75.86 \%$ and in male animals was $38.79 \%$. Similar results were obtained by Khan et al. (2010). These 
results may be attributed to pregnancy and lactation that cause rising in fecal egg count (Vlassoff et al., 2001). The rise in fecal egg count in female with specific physiological status may be attributed to relaxation of immunity and resistance (Valderrábano et al., 2006).

Some parasitologically positive animals appeared clinically normal. The clinical signs were severe emaciation, easily detached wool, pale mucous membrane and diarrhea in addition to bottle jaw in 2 cases. Our results were similar to those obtained previously by Yacob et al. (2009) who noticed that the severity of the clinical signs was related to the intensity of infection.

These clinical signs may be attributed to the decrease in the levels of serum total protein, albumin and globulin which lead to bottle jaw (Radostits et al., 2010). Beside that there was significant decrease in serum calcium (Hasan et al., 1986) and alkaline phosphatase. Moreover, there was significant reduction in bone mineral density (Thamsborg and Hauge, 2001). All these factors may lead to poor growth rate and emaciation. In addition, ulceration in abomasum and inflammation in intestinal wall interfere with digestion and absorption leading to diarrhea, emaciation and detached wool (Radostits et al., 2010). Severe anemia recorded by Yacob et al. (2009) caused pale mucous membrane.

The hematological changes associated with parasitic gastrointestinal nematode in sheep showed negative correlation between the degree of infestation and the levels of RBCs, $\mathrm{Hb}$ and PCV. There were significant decrease in levels of RBCs and PCV and a significant decreases in serum total protein, albumin and globulin levels. In addition, there were in all infested animals. These results agree with the results obtaind by Radostits et al. (2010). In addition, there was a significant decrease in levels of MCV and $\mathrm{MCH}$ in severely infected animals only. Our results nearly similar to results obtained by Yacob et al. (2009) who found that low level of infestation with Haemonchus contortus leading to normochromic normocytic anemia. These results may be attributed to the effect of the hemolytic factor that released from adult Haemonchus contortus on the surface of sheep RBCs lead to hemolysis (Fetterer and Rhoads, 1998). Moreover significant decrease in serum total protein, albumin and globulins levels were recorded. This may be attributed to the inflammatory enteropathy that occurred in the gastrointestinal tract and, in turn, the alteration of the intestinal micro-circulation, permeability and motility leading to albumin lossing enteropathy (Nesheim, 1993). Moreover, Rhodes et al. (1978) claimed that albumin might serve as a nutrient for the growing parasites and this might be responsible for the recorded hypoalbuminemia.

Post mortem examination of abomasum of sheep infected with Haemonchus contortus revealed thickening, hyperemia and small ulceration in addition to petechial hemorrhage at the site of worm attachment. The abomasal contents were dark in color and the adult worm was noticed grossly. Histopathologically, there were mononuclear cell infiltration in between mucosal glands and lamina propria beside necrosis and sloughing of mucosal epithelium and presence of adult worm. Similar results were previously obtained by Hertzberg et al. (2000).

Finally, it can be concluded that, the prevalence of gastrointestinal nematode among examined sheep was high especially in females during spring and in age group over 2 years. Trichostrongylus spp was the most detected nematode. Infected sheep showed anemia and decrease in serum total proteins, albumin and globulins levels. 


\section{REFERENCES}

Abdel-Wahed, M.M. and Salem, G.H. (1999): Diagnosis of gastrointestinal nematodes infecting sheep in Qalyoubia Governorate by infective third stage larvae. Journal of the Egyptian society of parasitology 29 (1): 101-106.

Agarwal, M.C. and Banerjee, P.S. (2007): Problems confronting helminthic diseases of domestic animals in India. J. Parasitol. Dis 31: 3-13.

Al-Gaabary, M.H.; Ammar, K.M.; Osman, S.A. and Hassan, A.I. (2007): Studies on parasitic gastroenteritis in sheep. Assiut Vet. Med. J. 53 (113): 169-188.

Altaif, K.I. and Issa, W.H. (1983): Epidemiology of gastrointestinal parasites of Awassi sheep in Iraq. Vet. Parasitology 12 (1): 51-58.

Aly, F.F.S.; Abdel-Allah, M. and AbdelRazeq, W.M. (1994): Nematodiasis in sheep at Sharqia Governorate; prevalence some biochemical studies and efficacy treatment. Alexandria Journal of Vet. Science 10 (1): 4550.

Bonfoh, B.; Zinsstag, J.; Ankers, P.; Pangui, L.J. and Pfister, K. (1995): Epidemiology of gastrointestinal nematodes in small ruminants in the Plateau area in Togo. Rev. Elev. Med. Vet. Pays. Trop. 48 (4): 321326.

Coles, E.H. (1989): Veterinary clinical pathology $4^{\text {th }}$ ed. W.B. Sounders company, Philadelphia, London, Toronts, Mexico, Sydney, Tokyo, Hong kong.

Doumas, B. (1971): Colorimetric determination of serum albumin. Clin. Chem. Acta. 400-403.

Drurag, R. and Wallington, E. (1980): Carlton's histological technique. $4^{\text {th }}$ ed. Oxford University press. New York.

El-Fayoumi, M.M.E. (1989): Some studies on parasitic gastroenteritis in sheep M.V.Sc. thesis (Animal \& fish diseases department); Fac. of Vet. Med. Cairo Univ.

Fetterer, R.H. and Rhoads, M.L. (1998): A hemolytic factor from Haemonchus contortus alters erythrocyte morphology. Vet. Parasitol.; 80 (1): 37-45.

Gharib, A.F.A.M. (1998): Some studies on the intestinal helminths of sheep with reference to Trichuris ovis. Thesis, ph.D. thesis (parasitology Department); Fac. of Vet. Med. Cairo Unv.

Hasan, S.G.; Soufi, H. and Hasanain, M.A. (1986): Some factors affecting wool moulting and reproductive activity in Barki sheep. Alexandria journal of veterinary sci. 2 (2): 119130.

Hashem, M. and El-Sayed, M. (1997): Helminth parasites of sheep in Daqahlia province Egypt. Assiut veterinary medical journal 38 (75): 48-54.

Henry, R.J. (1974): The colorimetric method for determination of total protein concentration. Clin. Chem. Harber and Row publishers, New York. 181.

Hertzberg, H.; Guscetti, F.; Lischer, C.; Neiger, R. and Eckert, J. (2000): Evidence for parasite-mediated inhibition of abomasal acid secretion in sheep infected with Ostertagia leptospicularis. The Vet. Journal 159: 238-251.

Horak, I.G. (2003): Parasites of domestic and wild animals in South Africa XLII. Helminths of sheep on four farms in Eastern cape province. Onderstepoort Journal Vet. Res. 70 (3): 175-186.

Kelly, W.R. (1984): Veterinary Clinical Diagnosis. 3rd ed. Baillieve tindal.

Khalafalla, RE.; Elseify, MA. and Elbahy, NM. (2011): Seasonal prevalence of gastrointestinal nematode parasites of sheep in Northern region of Nile 
Delta, Egypt. Parasitol Res.; 108(2): 337-40.

Khan, MN.; Sajid, MS.; Khan, MK.; Iqbal, Z. and Hussain, A. (2010): Gastrointestinal helminthiasis: prevalence and associated determinants in domestic ruminants of district Toba Tek Singh, Punjab, Pakistan. Parasitol Res. [Epub ahead of print].

Knox, M.R. and Steel, J.W. (1999): The effects of urea supplementation on production and parasitological responses of sheep infected with Haemonchus contortus and Trichostrongylus colubriformis. Vet. Parasitol.; 83 (2): 123-135.

Martin, S.W.; Meek, A.H. and Willeberg, P. (1987): Veterinary epidemiology. Iowa State University, Library of Congress., $3^{\text {rd }}$ ed.

Miller, J.E. and Horohov, D.W. (2006): Immunological aspects of nematode parasite control in sheep. J. Anim. Sci. 84 Suppl: E 124-132.

Nesheim, M.C. (1993): Human nutrition needs and parasitic infections. Parasitology, 107: S 7-S18.

Radostits, O.M.; Gay, C.C.; Hinchcliff, K.W. and Constable, P. (2010): Veterinary Medicine: A text of the diseases of cattle, horse, sheep, pigs and goats. $10^{\text {th }}$ ed. Bailliere, London, U.K.

Ramadan, E.I.; Kedees, M.H. and Hassan, A.A. (1992): Studies on helminth parasites of gastrointestinal tract of sheep and goats in Sinai Peninsula. Journal Egypt. Vet. Med. Ass. 52 (3): 411-422.
Reynecke, DP.; Van Wyk, JA.; Gummow, B.; Dorny, P. and Boomker, J. (2009): Validation of the FAMACHA((c)) eye colour chart using sensitivity/specificity analysis on two South African sheep farms. Vet Parasitol. [Epub ahead of print].

Rhodes, M.B.; Mc-Cullough, R.A.; Mebus, C.A. and Klucas, C.A. (1978): Ascaris summ: Specific

antibodies in isolated intestinal loop washings from immunized swine. Exp. Parasitol., 45: 255-262.

Soulsby, E.J.L. (1982): Helminths, Arthropoda and Protozoa of domesticated animals. $7^{\text {th }}$ ed. Baillier, Tindal and Cassel, London.

Thamsborg, S.M. and Hauge, E.M. (2001): Osteopenia and reduced serum alkaline phosphatase activity in grazing lambs naturally infected with gastrointestinal nematodes. Journal Comp. Pathol. 125 (2-3): 192-203.

Valderràbano, J.; Gomez-Rincón, C. and Uriarte, J. (2006): Effect of nutritional status and fat reserves on the periparturiant immune response to Haemonchus contortus infection in sheep. Vet. Parasitol. 141 (1-2): 122-131.

Vlassoff, A.; Leathwick, D.M. and Heath, A.C. (2001): The epidemiology of nematode infections of sheep. N.Z. Vet. J. 49 (6): 213-221.

Yacob, HT.; Mistre, Ch.; Adem, AH. and Basu, AK. (2009): Parasitological and clinical responses of lambs experimentally infected with Haemonchus contortus (L3) with and without ivermectin treatment. Vet. Parasitol.; 166 (1-2): 119-23. 
